\title{
KOMODIFIKASI PEKERJA PADA YOUTUBER PEMULA \\ DAN UNDERRATED \\ (Studi Kasus YouTube Indonesia)
}

\author{
Himmatul Ulya \\ himmaulya@outlook.co.id \\ Program Studi Magister Ilmu Komunikasi FISIP Universitas Diponegoro
}

\section{Article Info}

Keyword:

commodification of labor, YouTube, alienation, mystification, reification, naturalization

\begin{abstract}
The purpose of this research is to reveal commodification form and process which experienced by beginner and underrated YouTuber in Indonesia. This research uses a critical paradigm with qualitative approach through observation and indepth interview by developing political economy communication especially commodification of labor as a theoritical framework. Today, YouTuber is a profession that many Millenials appreciated because it can generate advantage in the form of popularity and commercial profit. The monetization and copyright feature on the YouTube platform was not able to be obtained by all creators, thus giving rise to the process of commodification labor. This research shows the commodification process that is not realized by YouTuber, especially beginner and underrated YouTuber through the YouTube partnership programs (YPP). The commodification form which experienced by YouTuber is the exploitation of content ownership and digital labor. Hence, YouTubers accept the exploitation as a fair demand because of process alienation, mystification, reification and naturalization.
\end{abstract}

\section{PENDAHULUAN}

YouTube, merupakan salah satu bentuk paltform media baru yang paling populer di Indonesia. Keleluasaan masyarakat yang dapat berperan sebagai kreator maupun penonton menjadi daya tarik tersendiri bagi masyarakat, terlebih tersedianya banyak pilihan konten semakin membuat youtube menjadi andalan media hiburan terlaris. Peningkatan khalayak aktif pengguna YouTube disinyalir mampu menandingi televisi sebagai media hiburan klasik, perbandingan prosentase pengguna YouTube berbanding sangat tipis dengan pengguna televisi yaitu; 57\% (Televisi) dan 53\% (YouTube) (Praditya, 2019).

Tingginya frekuensi minat audiens terhadap YouTube tentu tak terlepas dari peran kreator lokal maupun internasional yang menjadi penyedia konten dalam setiap unggahan video miliknya. sehingga, para kreator memiliki sebutan yang dikenal dengan YouTu- ber atau orang yang mengunggah video secara aktif dilaman YouTube. Berbagai konten yang disajikan oleh YouTuber dapat diakses oleh audiens melalui channel yang diciptakan oleh YouTuber melalui fasilitas YouTube creator studio.

Slogan YouTube "broadcast yourself" menjadi daya tarik tersendiri bagi para kreator konten untuk menyalurkan karyanya yang tidak memiliki tempat di media komersial seperti televisi. Mudahnya akses untuk mengunggah konten video akhirnya memiliki berbagai macam kepentingan dalam setiap video yang diunggah. Seperti penyebutan terhadap para kreator konten yang tidak mau menyebutkan dirinya sebagai YouTuber. Penggunaan media YouTube terkadang hanya dijadikan sebagai platform portofolio bagi sebagain kreator konten untuk membagikan karyanya kepada audiens atau sebagai bentuk sharing kepada sesama komunitas yang memiliki ketertarikan yang sama. Kemungkinan mereka menggunakannya untuk bersenang-senang, dibe- 
berapa komunitas, semua anggota komunitas memiliki peran masing-masing dalam sebuah internet sharing community. (Lessig, 2008)

Pengertian yang lainnya, merujuk pada konten kreator yang menyebut dirinya sebagai YouTuber, hal ini terjadi karena penamaan tersebut memiliki arti yang dianggap sebagai sebuah profesi. Yaitu sebagai salah satu profesi dunia pekerja kreatif, yang dapat menghasilkan konten untuk dimonetisasi sebagai bentuk dari penghasilan yang didapatkan melalui kreatifitas kreator konten. Hal inilah yang akhirnya banyak dimaknai oleh kebanyakan masyarakat umum terutama generasi milenial mengenai profesi YouTuber.

Maraknya penyedia konten yang aktif mengunggah video dengan berbagai konten yang bervariatif, membuat YouTube membuat kebijakan untuk memonetisasi konten melalui YouTube Partner Program (YPP) yang telah diresmikan pada tahun 2018. Keuntungan keanggotaan yang didapatkan oleh konten kreator dan YouTuber berupa adanya dukungan kreator ahli, copyright match tools dan fitur monetisasi. Untuk menjadi anggota YPP, konten kreator dan YouTuber harus mampu memenuhi persyaratan kelayakan minumum yang ditentukan oleh YouTube, yakni yang salah satunya berupa, memiliki lebih dari 1.000 subcriber pada akun channel milik konten kreator dan YouTuber. Adanya fitur monetisasi inilah yang akhirnya membedakan pengertian antara YouTuber dan konten kreator, perbedaan dalam peneyebutan ini dikarenan YouTuber disinyalir memiliki kepentingan untuk melakukan monetiasasi pada setiap video konten yang dihasilkan.

Hasil penelitian Yessi dkk (2017) mengenai komodifikasi masyarakat era jejaring, menunjukkan bahwa konten kreator menggunakan YouTube untuk memanfaatkan kreatifitas, ruang ekspresi diri, agar dapat berinteraksi dengan penonton sebagai bentuk komoditi yang dimanfaatkan oleh kreator untuk kepentingannya demi mendapatkan keuntungan berupa materil dan popularitas. Dan disaat bersamaan, YouTube, perusahaan pengiklan dan media network channel (MNC) istilah baru untuk production house yang menaungi manejemen youtuber juga memanfaatkan komiditi berupa minat khalayak atau masyarakat untuk kepent- ingan masing-masing. Sehingga keterbukaan masyarakat diera jejaring dapat dimanfaatkan oleh paltform media baru khususnya YouTube untuk meraih keuntungan. Selain itu Postigo (2014) juga menunjukkan adanya hubungan yang tidak berimbang dari bertemunya kreator dan khalayak dalam sebuah interaksi media baru melalui vlog channel game online. Yaitu, nilai tukar subcriber yang digunakan oleh kreator sebagai nilai jual untuk memonetisasi konten, dan secara tidak langsung khalayak dapat digambarkan sebagai bentuk dari digital labor.

Penelitian-penelitian sebelumnya juga menunjukkan bagaimana YouTube dapat menjadikan khalayak atau audiens sebagai co-produser bagi para penyedia konten atas interaksi yang terjadi antara khalayak dan kreator. Selain itu, YouTube juga akan memberikan penghargaan yang diberikan kepada YouTuber atas kerja kerasnya dalam membangun channel hingga mendapatkan puluhan juta viewer atau ratusan juta $s u b$ criber, melalui play button berupa silver yang telah memiliki seratus ribu subcriber, Gold satu juta lebih subcriber, diamond sepuluh juta subcriber dan ruby seratus juta subcriber. Penghargaan tersebut merupakan sebuah pencapaian prestisius bagi para YouTuber, untuk mendapatkannya Youtuber perlu bekerja keras membuat konten yang dapat menarik viewer dan $s u b$ criber. Konten yang dihasilkan diharapkan mampu dimonetisasi, namun seiring dengan belum terpenuhinya persyaratan kelayakan minimun YPP, hal tersebut menjadi mustahil. Padahal untuk membuat konten yang menarik membutuhkan usaha yang luar biasa dari pembuat konten.

Penghasilan tinggi dari monetisasi yang dihasilkan oleh para YouTuber atas perolehan viewer dan subcriber membuat banyak orang tertarik untuk terjun menjadi seorang YouTuber. Channel milik Atta Halilintar dan Ria Ricis misalnya, yang berhasil memiliki jutaan pengikut dan penonton menjadi acuan bagi para generasi milenial untuk berkarir sebagai YouTuber. Namun untuk memiliki subcriber dan viewer yang sesuai dengan kebijakan YPP, YouTuber harus melalui proses yang cukup panjang, sehingga tak jarang proses tersebut mengalami berbagai kendala serius yang dihadapi oleh YouTuber. 
Seperti, bermodalkan konten video yang apik tidak cukup untuk mendapatkan monetisasi tanpa memiliki subcriber dan viewer yang telah ditentukan oleh minimum YPP, sehingga tak jarang ditemukan beberapa YouTuber yang menutup akun channelnya secara permanen, karena tidak cukup untuk mengembalikan modal pembuatan konten yang berharap pada pendapatan monetisasi, padahal konten yang dihasilkan cukup berkualitas. Atau pencurian hasil karya footage milik kreator yang diambil untuk tujuan komersial tanpa memiliki izin yang legal dari pemilik konten. Seperti pada kasus pengambilan footage oleh stasiun televisi swasta yang mengambil dari salah satu hasil karya kreator tanpa melibatkan credit kepemilikan konten.

Hasil penelitian Subandi dkk (2018) menunjukkan adanya bentuk komodifikasi terhadap media baru yang mencakup komodifikasi isi, konten dan pekerja pada Line Webtoon. Proses komodifikasi pekerja yang terjadi merujuk adanya sebuah kebijakan yang dibuat oleh Webtoon yang mengajak khalayak untuk berkarya menjadi kreator dan mengikuti Webtoon Challenge. Namun, hasil dari karya tersebut tidak mendapatkan bayaran sama sekali, sedangkan Webtoon mendapatkan keuntungan materil berupa akses khalayak terhadap karya tersebut, sehingga terjadi praktik nilai guna keahlian kreator menjadi nilai jual. Merujuk pada penelitian - penelitian terdahulu maka, peneliti menyimpulkan bahwa terdapat berbagai model komodifikasi yang terjadi atas perkembangan teknologi di era media baru, khususnya media yang menggunakan kreativitas khalayak sebagai komponen dalam mengembangkan platform.

Peneliti menduga terjadi eksploitasi yang dilakukan oleh YouTube terhadap YouTuber dalam proses untuk mendapatkan monetisasi atau copyright, terutama pada YouTuber pemula dan underrated melalui kebijakan YPP yang mengikat semua kreator konten YouTube. YouTuber pemula merupakan kreator konten yang sedang mengembangkan akun channelnya untuk tujuan komersil dan mencari popularitas dalam jangka waktu enam bulan sampai satu tahun. Sedangkan YoutTuber underrated merupakan kreator konten yang belum berhasil memiliki minimal 1.000 subcriber dalam jangka waktu satu tahun lebih dan tidak memiliki jumlah penonton yang cukup banyak.

Sementara itu, peneliti juga melihat bentuk mistifikasi yang dilakukan oleh YouTube melalui slogan "Broadcast Yourself", YouTube berusaha untuk mengajak khalayak untuk berpartisipasi sebagai kreator dan di imingi dengan tawaran monetisasi. Padahal mereka tidak sadar bahwa apa yang sudah mereka unggah dalam platform menjadi konten milik YouTube "broadcast yoursefl, (as long as content it's ours)" (Wasko, 2009). Selain itu, fenomena YouTuber juga telah merambah dunia akademis, seperti yang terjadi di salah satu universitas negeri di Jakarta yang menyebutkan persyaratan kepada calon mahasiswa yang akan mengikuti beasiswa jalur prestasi harus memiliki akun channel YouTube dengan minimal 10.000 subcriber.

Berdasarkan wawancara yang dihimpun oleh salah satu YouTuber asal Medan, penghasilan yang dihasilkan oleh YouTuber Indonesia tidak sesuai dengan perolehan YouTuber asal negara lain karena adanya RPM (Revenue per Mille Impression). Hal ini ternyata dipengaruhi oleh ketentuan lokalisasi yang diterapkan oleh kebijakan YouTube, ketentuan lokalisasi tersebut akhirnya menciptakan gap terhadap perbedaan rate setiap klik-nya yang dipengaruhi oleh faktor negara asal pemilik akun.

Selain itu, adanya ketentuan YPP membuat YouTuber pemula dan underrated tidak mendapatkan perlindungan konten, seperti hak cipta atau copyright pada kepemilikan konten. Hal tersebut kemudian menimbulkan kewajaran yang dinatruralisasi dari kebijakan YPP dalam menggugurkan adsense untuk memonetisasi konten ketika video tidak sesuai dengan ketentuan minimum YPP. YouTuber tidak akan mendapatkan hasil kerjanya melalui monetiasi jika belum mendapatkan 1.000 subcriber, tetapi YouTube mendapatkan hasil dari konten yang diakses oleh khalayak.

Berdasarkan fenomena tersebut, peneliti melihat adanya komodifikasi pekerja yang dilakukan oleh YouTube melalui YouTube Partnership Program (YPP) terhadap kreator konten dan YouTuber khususnya pemula dan underrated. Untuk itu, penelitian ini bertujuan untuk menunjukan bagaimanakah bentuk eksploitasi yang dialami oleh YouTuber? Dan 
bagaimana YouTuber mengalami proses komodifikasi pekerja yang dilakukan oleh YouTube?

\section{KAJIAN PUSTAKA}

Metodologi

Penelitian ini menggunakan paradigma kritis, Guba dan Lincoln mendefinisikan paradigma sebagai serangkaian keyakinan-keyakinan dasar (basic beliefs) atau metafisika yang berhubungan dengan prinsipprinsip utama atau prinsip-prinsip pokok (Sunarto, 2011). Paradigma kritis mempunyai beberapa karakteristik: meyakini bahwa refleksi dan kritik metode untuk menghasilkan pengetahuan bukan melalui observasi; lebih dari sekedar data kuantitatif dan kualitatif; ideologi dan kekuasaan ada dalam pengalaman sosial; tujuan penelitian untuk perubahan sosial. (Sunarto, 2011).

Peneliti menggunakan paradigma kritis, karena peneliti melihat kerisauan atas munculnya fenomena yang dihadapi oleh generasi milenial dalam melihat YouTuber sebagai profesi pekerjaan di bidang industri kreatif yang menguntungkan. Padahal tanpa diketahui secara umum profesi tersebut mengalami proses eksploitasi yang dilakukan oleh YouTube. Eksploitasi tersebut sama sekali tidak terlihat bagi kalangan umum bahwa video konten yang dihasilkan tidak selalu menghasilkan monetisasi, mereka meyakini apa saja yang dapat diunggah di kanal YouTube dapat menghasilkan monetisasi. Sehingga, penelitian ini diharapkan mampu mengedukasi masyarakat bahwa untuk menjadi kreatif konten khususnya, YouTuber, kartunis, vlogger dan lain sebagainya tidaklah mudah, perlu memiliki keahlian dan strategi yang lihai untuk meningkatkan jumlah viewer dan subcriber yang menjadi syarat mutlak untuk mendapatkan keuntungan komersil.

Penelitian ini dilakukan menggunakan pendekatan kualitatif. Penelitian kualitatif adalah penelitian yang bermaksud untuk memahami fenomena tentang apa yang dialami oleh subjek penelitian misalnya perilaku, persepsi, motivasi, tindakan dan lain-lain, secara holistik, dan dengan cara deskriptif dalam bentuk kata-kata dan bahasa, pada suatu konteks khusus yang alamiah dan dengan memanfaatkan berbagai metode alamiah
(Moeleong, 2013).

Metode penelitian yang dilakukan adalah penelitian dengan menggunakan studi kasus. Creswell (1998) menyatakan bahwa studi kasus adalah suatu model yang menekankan pada eksplorasi dari suatu sistem yang terbatas (bounded system) pada suatu kasus atau beberapa kasus secara mendetail, disertai dengan penggalian data secara mendalam yang melibatkan beragam sumber informasi yang kaya akan konteks. Yin (dalam Bungin, 2005) menyatakan bahwa studi kasus adalah suatu inquiry empiris yang mendalami fenomena dalam konteks kehidupan nyata, ketika batas antara fenomena dan konteks tak tampak dengan tegas (Herdiansyah, 2010).

Teknik dalam pengumpulan data dilakukan dengan menggunakan dua cara yang pertama adalah observasi partisipatoris. Observasi ini merupakan jenis observasi yang tidak hanya menempatkan peneliti hanya sebagai pengamat (Endah P, 2011). Salah satu variasi pengambilan data adalah dengan peneliti terlibat langsung atau menjadi bagian dari responden dan interaksi dengan responden. Kedua adalah metode wawancara mendalam (Depth Interview). Metode depth interview merupakan dapat dilakukan dengan tatap muka secara mendalam dan terus-menerus (lebih dari satu kali) untuk menggali informasi dari responden (Kriyantono, 2006).

Terdapat tiga informan utama dalam penelitian ini yaitu tiga kreator YouTube bernama Rizki Andri Harahap, Sam Pradana dan Dodik Wijaya. Satu diantaranya merupakan YouTuber yang telah berhasil mendapatkan adsenses pada akun channelnya, sedangkan dua yang lain merupakan YouTuber pemula dan underrated.

Analisis data kualitatif adalah upaya yang dilakukan dengan jalan pekerja dengan data, mengkategorisikan data, dan memilah-milah menjadi satuan yang dapat dikelola, mensistesiskannya, mencari dan menemukan pola, menemukan apa yang penting dan apa yang dipelajari dan memutuskan apa yang dapat diceritakan kepada yang lain (Moeleong, 2013). Proses analisis yang dilakukan oleh peneliti diawali dengan mengumpulkan observasi lapangan berupa data tertulis maupun lisan mengenai proses yang dilakukan oleh YouTuber dalam membuat konten. Berdasarkan ob- 
servasi tersebut, peneliti melakukan depth interview untuk melihat bagaimana proses yang dialami oleh YouTuber dalam menjalankan profesinya sebagai kreator konten. Hasil dari wawancara tersebut kemudian dirubah menjadi transkrip wawancara yang dilengkapi dengan data dari hasil catatan lapangan penelitian. Selanjutnya, deskripsi observasi dan transkrip wawancara dinarasikan sesuai dengan data yang dibutuhkan. Kemudian, data dianalisis menggunakan kerangka konseptual untuk menguji hipotesis penelitian (Labas, 2017).

\section{Kajian Konseptual}

Ekonomi politik komunikasi menjadi kajian kritis dalam melihat media membangun relasi sosial untuk menguasai berbagai sektor produksi. Menurut Vincent Mosco terdapat tiga proses yang menjadi pintu masuk bagi ekonomi politik komunikasi, yaitu; komodifikasi, spasialisasi dan strukturisasi (Mosco, 2009). Komodifikasi merupakan bentuk dari proses transformasi barang dan jasa yang dinilai dari kegunaannya menjadi suatu komoditas yang dapat dipasarkan yang dinilai dari nilai tukarnya.

Komodifikasi terjadi melalui proses produksi dimana pemilik modal atau kapitalis membeli komoditas kekuatan tenaga kerja (labour power) dan alat-alat produksi (the means of production) untuk menghasilkan nilai lebih (surplus value) yang bisa digunakan untuk meraih keuntungan yang lebih besar. Selama berlangsungnya proses pengembangan keuntungan terjadi proses eksploitasi (exploitative process) yang dialami oleh pekerja. Bentuk komodifikasi dalam komunikasi ada tiga, yaitu komodifikasi isi, komodifikasi khalayak dan komodifikasi pekerja (Mosco, 2009).

Komodifikasi isi, berupa proses yang dilakukan oleh kapitalis untuk meraup keuntungan melalui isi atau konten suatu program yang disukai oleh khalayak dan dapat menghasilkan rating yang cukup tinggi. Komodifikasi khalayak, merupakan proses saat rating dijadikan sebagai komiditas nilai jual untuk meraup keuntungan. Sedangkan komodifikasi pekerja berupa proses yang dilakukan oleh kapitalis untuk menekan pekerja melalui eksploitasi untuk meraup keuntungaan. Eksploitasi yang dialami oleh pekerja dapat melalui dua jalan, yaitu mengatur fleksibelitas dan kontrol atas pekerja dan menjual pekerja tersebut untuk meningkatkan nilai tukar dari isi pesan media (Mosco, 2009). Dangan adanya perkembangan teknologi, jalan pertama berupa fleksibelitas dan kontrol atas pekerja semakin mudah untuk dilakukan. (YouTube, Flickr, Google).

Perkembangan teknologi khususnya di era digitalisasi media, platform media baru menggunakan khalayak aktif sebagai pekerja untuk meningkatkan kapasitas rate platform. Sehingga paltform tersebut mendapatkan keuntungan komersil sedangkan pengguna atau user tidak mendapatkan keuntungan, hal ini umum terjadi di berbagai platform media baru. Seperti pada Google yang mengembangkan platform melalui konten yang dihasilkan oleh khalayak. Andrew Keen berpendapat bahwa, Google merupakan sebuah parasit, karena membuat konten yang tidak dimilikinya sendiri (Lessig, 2008). Hal ini pun dapat ditemukan pada platform YouTube karena konten diciptakan oleh khalayak, YouTube hanya berperan sebagai penyedia platform yang menampung semua kreativitas yang diciptakan oleh para kreator.

\section{Komodifikasi Pekerja}

Menurut Karl Max, terdapat dimensi-dimensi yang menunjukan bahwa pekerja mengalami komodifikasi secara bertahap yaitu melalui eksploitas, alienasi, mistifikasi, reifikasi dan naturalisasi (Rahmiaji, 2016). Alienasi merupakan bentuk keterasingan pekerja dalam pekerjaanya sendiri setelah mengalami bentuk eksploitasi, apa yang seharusnya menjadi produk pekerja tidak menjadi keuntungan terbesar pekerja. Hal ini berkaitan dengan Youtuber pemula dan underrated yang tidak memiliki keuntungan dari konten yang diunggah di paltform YouTube karena belum memenuhi standar YPP.

Mistifikasi menurut Karl Max merupakan tampilan palsu (false appearance) atau makna palsu (false meaning). Mistifikasi atau pemesonaan tercipta ketika suatu komoditas diputuskan dari para pekerja yang memproduksinya dan dari fungsi pakai komoditas tersebut, sehingga dalam suatu proses pertukaran komoditi diperkaya denga makna-makna tertentu yang lebih dari sekedar nilai guna (Rahmiaji, 2016). Seperti pada YouTuber yang dianggap memiliki daya kreativitas tinggi dan dianggap sebagai pekerja kreatif yang 
mendapatkan eksistensi dijagat maya dan menghasilkan monetisasi pada setiap konten yang diunggah, sehingga memunculkan sebuah keyakinan oleh sebagian masyarakat sebagai sebuah profesi yang menjanjikan.

Reifikasi diartikan dengan penilaian sebuah kesuksesan yang diukur dari sejumlah benda atau ambisi untuk mendapatkan penghargaan. Dalam kasus YouTuber, mereka berlom-lomba untuk mendapatkan penghargaan prestisius button play berupa ruby, diamond, gold dan silver. Naturalisasi merupakan upaya dari pekerja untuk menganggap normal, biasa dan wajar dari relasi pekerja dan pemilik modal. Dari sudut pandang kapitalis, relasi sosial yang dinaturalisasi adalah bentuk dari eksploitasi terhadap pekerja, sehingga hasil akhir dari naturalisasi adalah penerimaan terhadap eksploitasi tersebut.

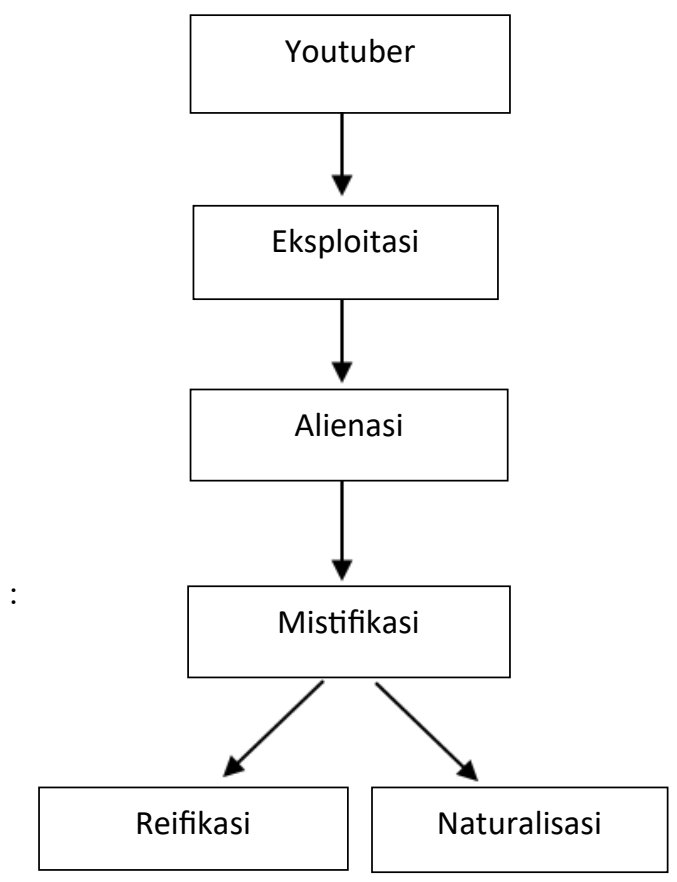

Gambar 1. Kerangka Penelitian Komodifikasi Youtuber

\section{TEMUAN DAN DISKUSI}

Penelitian ini bermula saat peneliti bertemu dengan salah satu YouTuber Pemula yang mengeluhkan tentang ketatnya syarat sebuah channel untuk mendapatkan uang dan iklan melalui kebijakan YouTube Partnership Program (YPP). Peneliti melakukan observasi sederhana yang dilakukan di salah satu kelas menengah pertama SMP IT Roudhotus
Sholihin tentang ketertarikan mereka untuk menjadi seorang YouTuber. Dari 25 siswa, 10 diantaranya berkeinginan untuk menjadi YouTuber, menurutnya YouTuber merupakan salah satu profesi dunia kreatif yang mudah untuk menghasilkan keuntungan berupa popularitas dan komersil. Jika seseorang telah dikenal dengan baik melalui salah satu platform media baru seperti YouTube, maka ia juga akan mudah dikenal di platform media baru lainnya, seperti Instagram dan Twitter, yang kemudian muncul istilah selebgram dan selebtweet. Dengan pemikiran sederhana seperti ini, membuat masyarakat terutama generasi milenial berkeinginan untuk menjalani profesi sebagai YouTuber.

Pemahaman tentang profesi YouTuber yang mudah mendapatkan popularitas dan komersial mengaburkan bagaimana proses untuk mendapatkan monetisisasi yang cukup ketat. Berdasarkan fakta-fakta dan datadata yang dihimpun, penelitian ini mengungkapkan proses yang menunjukkan bentuk eksploitasi yang dialami oleh YouTuber dan komodifikasi pekerja yang dilakukan oleh YouTube.

\section{Kepemilikan Konten}

Menurut Karl Marx, pekerjaan yang mengasingkan adalah pekerjaan upahan. Seseorang yang bekerja untuk orang lain tidak akan memikirkan dirinya sendiri, melainkan bekerja dengan terpaksa untuk mendapatkan upah. Pekerjaan upahan hanya menjadi sebagian dari hak milik pribadi, karena sistem hak milik pribadi memisahkan antara pemilik dan pekerja, sehingga keterasingan pekerja adalah akibat dari hak milik pribadi.

Hal ini dirasakan oleh semua pekerja kreator konten YouTube, karena YouTube memiliki hak yang mutlak atas kepemilikan konten milik kreator yang diunggah di platform tersebut. "Broadcast youself (as long as contens its ours)". Kalimat tersebut menggambarkan bagaimana YouTube dapat menguasai semua konten milik kreator yang diunggah dalam paltform tersebut. Sehingga terjadi hubungan antara pemilik paltform dan pekerja platform sebagai pengisi konten. Jika konten dari sebuah channel tidak memiliki standar kelayakan minimum YPP maka hasil dari karya tersebut tidak dapat dimonetisasi dan tidak mendapatkan hak copy- 
right dari hasil karyanya, padahal dari setiap akun channel yang diakses oleh khalayak, YouTube mendapatkan keuntungan. Hal inilah yang selalu ditakutkan oleh YouTuber baik pemula, underrated maupun yang sudah terverifikasi melalui button play certified.

\section{a) Tidak memiliki copyrigt}

Bagi YouTuber pemula atau underrated, konten yang diunggah tidak memiliki copyright, sebelum memenuhi syarat minimum YPP. Sehingga rentan terjadi pencurian hasil karya kreator berupa pencurian footage dari berbagai pihak, apalagi jika hasil karya tersebut dikomersilkan.

"Copyright atau hak cipta itu sangat diperlukan oleh para kretaor, karena banyak pencurian video yang tidak menyebutkan sumber asli".

Seperti yang terjadi pada hasil karya seorang kreator yang diambil oleh stasiun televisi swasta yang digunakan untuk visualisasi salah satu program acara televisi dan diunggah kembali di laman channel YouTube dengan menambahkan watermark milik televisi tersebut. Hak cipta dari konten yang diunggah terlihat seperti milik televisi tersebut, sedangkan pemilik konten yang asli kehilangan karyanya yang kemudian ditarik oleh YouTube karena memiliki kesamaan konten dengan channel lain yang terverifikasi oleh YPP . Padahal, proses untuk membuat konten tidak mudah, dari fenomena tersebut akhirnya memunculkan masalah yang lain tentang kepemilikan konten yang cukup serius karena terjadi praktik pelanggaran Hak Atas Kekayaan Intelektual (HAKI) seorang kreator.

\section{2..Digital Labour}

Menurut Fuchs dan Sevigani, digital labour merupakan bentuk eksploitasi dari pengguna media sosial yang tidak dibayar, yang menjadi bagian dari kreativitas konten dan penggunaan blog, jaringan media sosial, dan aktivitas tersebut merupakan nilai kreativitas untuk mencari keuntungan yang banyak disukai oleh generasi milenial (Fuchs, 2013). Kreativitas konten tersebut kemudian digunakan oleh YouTube untuk mencari keuntungan melalui tingginya akses khalayak yang dipengaruhi oleh variasi konten dari kreator.

Ekploitasi yang dialami oleh youtuber dalam isu digital labor dapat dilihat dengan menggunakan dua perspektif, yaitu eksploitasi absolut dan ekslpoitasi relatif. Eksploitasi absolut merupakan bentuk eksploitasi yang dialami oleh semua konten kreator dan YouTuber baik pemula, underrated maupun verified, yaitu berupa :

\section{a. Tidak ada jam kerja}

Pekerjaan YouTuber merupakan pekerjaan yang disinyalir cukup santai dan terkesan membebaskan pemilik channel untuk membuat konten tanpa batas waktu yang ditentukan. Namun, hal ini sangat bertentangan dengan yang dirasakan oleh para YouTuber, disatu sisi mereka merasa bebas karena tidak ada jam kerja, tetapi disisi lain mereka memiliki jam kerja yang tidak dapat ditentukan, karena hal ini berkaitan dengan self production atau memproduksi konten secara mandiri.

\begin{abstract}
"Semua tergantung pada diri YouTuber, apakah profesi ini dijadikan sebagai main job atau side job. Tapi, meskipun main atau side job, YouTuber sama sekali tidak memiliki jam kerja. Seluangnya saja, bahkan saya pernah mengedit konten sampai beberapa hari".
\end{abstract}

Hasil wawancara ini menunjukkan bahwa YouTuber tidak memiliki jam kerja yang tetap, selain itu, syarat kelayakan minimun dari YPP menyebutkan, bahwa; YouTube berhak menghapus monetisasi channel jika sudah tidak aktif selama 6 bulan dan monetisasi dapat dicabut jika waktu jumlah penonton dan subcriber menurun. Hal inilah yang membuat tekanan bagi para YouTuber, bagaimana mereka dapat menciptakan konten yang menarik tanpa harus kehilangan jumlah penonton dan subcriber, dengan begitu tentu saja YouTuber membutuhkan waktu untuk bekerja lebih lama dalam memproduksi konten yang menarik dan tidak memiliki jam kerja yang jelas.

\section{b. Self Production}

Broadcast Yourself, secara tidak langsung YouTube telah memberikan gambaran bahwa YouTu- 
ber dan kreator konten bekerja sendiri untuk membuat konten. Hal ini terjadi karena, YouTube memang menyasar para kreator kreatif yang tidak memiliki tempat di media massa, sehingga YouTube memberikan fasilitas dan mengakomodir konten untuk dinikmati oleh khalayak.

"Tantangan menjadi YouTuber itu salah satunya bagaimana kita dapat membuat dan mengedit video sendiri. Disinilah letak kepuasaan hasil karya kalau berhasil ditonton banyak orang”.

Berdasarkan wawancara yang dihimpun, YouTuber merupakan kreator konten di kanal YouTube yang membuat, mengedit atau menciptakan video yang akan diunggah ke platform media YouTube. Sehingga konten yang dibuat oleh YouTuber cenderung dibuat mandiri, meskipun beberapa kreator telah memperkejakan crew yang biasanya dilakukan oleh kretaor yang memiliki penghasilan tinggi atau menjadi bagian dari media network channel (MNC). Yaitu production house yang menaungi YouTuber dengan keuntungan yang dibagi antara MNC dan YouTuber. Self production, inilah yang menjadi salah satu tekanan bagi para YouTuber untuk membuat konten yang menarik dan dapat diterima baik oleh khalayak.

Eksploitasi relatif yang dialami oleh YouTuber merupakan intensifikasi proses tenaga kerja, bagaimana YouTuber dapat meningkatkan kemampuan atau memaksimalkan konten agar memenuhi standar kelayakan minimum YPP. Hal ini ternyata banyak dilakukan oleh hampir semua YouTuber untuk memikat subcriber dan penonton yaitu berupa :

\section{a) Self Promotion}

Subcriber menjadi salah satu acuan yang mutlak bagi para YouTuber untuk memperoleh monetisasi, sehingga hal yang paling sering dilakukan adalah bagaimana cara menarik khalayak atau audiens untuk menjadi subcriber bagi pemilik channel. Banyak hal kreatif yang dilakukan oleh YouTuber, salah satunya membuat visualisasi yang menarik untuk mengajak audiens menge-klik tombol subcriber pemillik channel, atau hal lain yang biasa dilakukan oleh kebanyakan YouTuber, yaitu dengan melakukan self promotion untuk mengajak khalayak meng-klik tombol subcriber yang biasanya diucapkan didalam konten video.

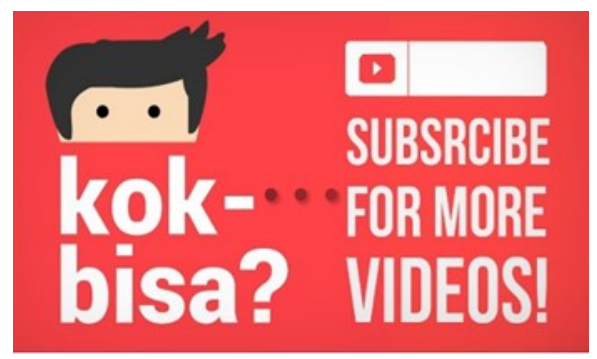

Gambar 2. Kreativitas YouTuber untuk menarik subcriber

\section{b) Khalayak Pasar}

Khalayak atau audiens menjadi tolak ukur yang sangat penting bagi YouTuber sebagai pangsa pasar untuk mendapatkan keuntungan komersil.

"Biasanya setelah YouTuber berhasil membuat konten yang pecah, mereka akan terus melanjutkan konten tersebut, demi mempertahankan penonton”.

Pemilihan konten yang banyak diminati oleh khalayak menjadi senjata atau amunisi yang akan terus digunakan oleh YouTuber untuk mendapatkan perhatian dari khalayak. Seperti pada akun milik Atta Halilintar yang memiliki banyak konten berupa "prank" yang menjadi andalannya dalam menarik audiens. Atau channel milik Rizki Andri Harahap yang lebih banyak memberikan tutorial cat rambut sebagai salah satu konten andalannya. Sehingga segala sesuatu yang dapat menarik perhatian masyarakat akan selalu diandalkan oleh YouTuber untuk meraih popularitas dan keuntungan materil.

\section{c) Audiens Internasional}

Salah satu hal yang membuat YouTuber ingin meningkatkan pendapatannya adalah membuat konten yang dapat menyasar audiens internasional. Hal ini dilakukan kerena pendapatan YouTuber berbeda - beda diberbagai negara, adanya kebijakan revenue per mille impression (RPM) terlihat seperti mengkotak -kotakan hasil karya kreator berdasarkan negara, yang tentu saja bersebrangan dengan asas internet sebagai ruang publik tanpa batas atau borderless.

“ karena begini, dua orang viewer dari Singapu- 
ra menonton channel milik kita, hasilnya sama dengan 10 orang viewer dari Indonesia jika di konversikan, jadi kadang banyak juga YouTuber yang menyasar orang-orang luar"

Berdasarkan wawancara dan analisa data-data yang dihimpun, channel yang meyasar audiens internasional seperti Singapura dengan jumlah penonton sedikit mampu mengalahkan channel yang memiliki ratusan ribu penonton dari Indonesia dalam hal earning atau monetisasi. Perbandingan tersebut tentu sangat besar, sehingga banyak kreator YouTuber menyasar audiens internasional.

\section{Alienasi}

Alienasi merupakan bentuk keterasingan pekerja yang dialami atas pekerjaanya sendiri, yaitu berupa hal yang dilakukan pekerja tetapi tidak dapat dinikmati oleh pekerja itu sendiri. Keterasingan menurut Karl Marx, merupakan salah satu dari bentuk sistem kapitalis yang membuat orang bekerja tanpa memikirkan dirinya sendiri melainkan semata-mata terpaksa karena upah. Sehingga pekerjaan disinyalir tidak dapat mengembangkan, melainkan mengasingkan manusia, baik dari dirinya sendiri maupun orang lain.

Hal ini sangat berkaitan dengan profesi YouTuber, beberapa YouTuber melakukan pekerjaan dengan membuat konten yang menarik tetapi hasil yang diperoleh tidak dapat dinikmati secara keselurahan. YouTuber seperti terkungkung dan berfokus terhadap penciptaan konten video yang menarik untuk memenuhi standar kelayakan YPP dan juga pasar, sehingga tidak sempat untuk memperhatikan diri sendiri, keluarga dan lingkungan sosial. Bahkan diantaranya ada yang harus merelakan pendidikan untuk berfokus terhadap karir sebagai Youtuber profesional yang diakui oleh khalayak. Selain itu, proses dalam membuat konten terkadang harus melakukan sesuatu yang berbeda dari kemampuannya untuk menarik penonton dan membahayakan keselamatan maupun kesehatan YouTuber.

“ kadang gak punya waktu buat bermain sama temen-temen kalau sedang fokus banget membuat video. Kalau video sudah selesai di edit, biasanya akan terpikir untuk membuat konsep seperti apalagi ya di next video."
"YouTuber yang langsung punya nama biasanya sudah terkenal, biasanya banyak bikin konten yang out of the box"

Melihat hasil wawancara tersebut, YouTuber telah mengalami keterasingan dari dunia luar, ditambah dengan usaha YouTuber yang ingin segera meraih popularitas dengan melakukan berbagai hal yang dapat membayakan YouTuber. Proses alienasi yang terjadi tentu saja berhubungan dengan eksploitasi yang dialami oleh YouTuber. Seperti self production dan tidak ada jam kerja yang tetap. Selain itu, tidak adanya jam kerja membuat YouTuber mampu berlama-lama untuk memikirkan konsep dan konten apa saja yang akan diciptakan dengan melakukan editing dan produksi secara mandiri. Hal inilah yang akhirnya membuat profesi YouTuber mengalami keterasingan dari luar (alienasi) sebagai salah satu bentuk dari profesi baru di dunia kreatif, ditambah kecenderungan masyarakat memahami profesi kreatif sebagai bentuk dari keterasingan antara pekerja dan dunia luar.

\section{Mistifikasi, Reifikasi dan Naturalisasi}

Mistifikasi menurut Karl Max merupakan tampilan palsu (false appearance) atau makna palsu (false meaning). Mosco menyatakan, dalam pandangan marxian, komoditas mengobjektifikasi eksploitasi relasi sosial, "by presenting them in a congealed form that makes them natural. Konsepsi tenaga kerja sebagai komoditas ditampakkan dengan seperangkat nilai guna dan nilai tukar yang spesifik nilainya dilihat dari harganya dipasaran. Nilai inilah yang kemudian mengaburkan (memistifikasi) kemampuan memahami tenaga kerja sebagai satu kesatuan antara konsepsi dan eksekusi, perwujudan dari proses kerja, berbagai stratifikasi relasi kerja antara kelas, gender, dimensi nasional dan spasial (Rahmiaji, 2016).

Mistifikasi yang dilakukan oleh YouTube dapat dilihat melalui pengembangan makna-makna yang identik dengan status kreator konten sebagai YouTuber. YouTuber sering ditafsirkan oleh sebagian besar masyarakat terutama generasi milenial sebagai peker- 
jaan santai yang menghasilkan banyak profit. Ditambah dengan pelabelan nama YouTuber sebagai selebtube, memunculkan fantasi popularitas sebagai pekerja entertainment yang dapat merasionalisasi penerimaan komodifikasi pekerja. Yang artinya menjadi YouTuber dapat menghasilkan dua keuntungan berupa popularitas dan keuntungan komersil.

Dampak popularitas yang didapatkan oleh YouTuber berupa peningkatan materi yang dihasilkan melalui monetisasi konten dan peningkatan status sosial yang sering disebut sebagai influencer digital. Dengan penyebutan tersebut akhirnya mampu mengaburkan makna yang sebenarnya dan YouTuber tidak dilihat sebagai seorang pekerja kreatif namun sebagai seorang yang menjadi panutan bagi orang lain. Kesadaran tersebut kemudian digunakan oleh berbagai pihak untuk meraup keuntungan komersil, seperti munculnya pelatihan untuk menjadi seorang YouTuber dari berbagai MNC (Media Network Channel) yang dikenakan biaya kepada peserta, padahal untuk menjadi seorang YouTuber yang mampu menghasilkan profit harus melalui proses yang tidak mudah, dan proses inilah yang akhirnya dikaburkan (dimistifikasi) dan tidak diketahui secara umum oleh masyarakat.

Berdasarkan wawancara yang dihimpun, untuk meraih profit atau monetisasi konten, YouTuber harus memiliki konten yang diminati oleh khalayak dan standar kelayakan minimun melalui YPP. Jika hal tersebut telah terpenuhi maka YouTuber akan mendapatkan monetisasi dari hasil konten yang diciptakan. Bahkan jika subcriber dan viewer telah menembus angka minumum, maka YouTuber layak mendapatkan penghargaan prestisius yang diberikan oleh YouTube berupa silver button play, gold button play, diamond button play dan ruby button play.

"Setiap YouTuber pasti berharap mendapatkan penghargaan button play"

Dengan meraih penghargaan tersebut, popularitas YouTuber dapat meningkat dan akan meningkatkan keuntungan yang didapatkan oleh YouTuber, seperti bertambahnya adsense dan tawaran iklan off air.

“YouTuber atau pekerja kreatif kalau sudah sukses biasanya sering disebut influencer"

Popularitas YouTuber yang didapatkan dengan memiliki penghargaan button play, sering kali dianggap sebagai influencer oleh masyarakat. Untuk dianggap sebagai influencer, YouTuber harus fokus pada konten tertentu, seperti pada koneten games, kecantikan, olahraga dan tata boga atau yang lainnya. Sehingga pemaknaan profesi YouTuber sebagai profesi khusus yang berbeda dari pekerjaan lainnya dapat dilihat sebagi bentuk reifikasi. Hampir semua Youtuber baik yang dikenal maupun belum dikenal bangga dengan profesinya, karena dipandang sebagai pekerja di dunia kreatif yang berbeda dari lainnya dan tidak mudah dilakukan oleh masyarakat umum. Ditambah jika seorang YouTuber telah memiliki nama, maka ia akan juga dikenal sebagai influencer. Dengan predikat tersebut, YouTuber melupakan posisinya sebagai pekerja.

"Membuat konten sampai proses selesai itu tidak mudah, butuh effort yang cukup besar agar diterima oleh masyarakat. Makanya, jika konten video tidak menghasilkan profit terkadang saya merasa kecewa, tapi kembali lagi apakah video yang kita bikin sesuai dengan yang disukai oleh masyarakat atau tidak"

"Kalau syaratnya sudah begitu yasudah, kita tidak bisa protes, berarti konten kita kurang menarik”

Berdasarkan hasil wawancara, naturalisasi yang dijalankan oleh YouTuber merupakan bentuk adaptasi dari ketentuan YPP, yang menyebutkan bahwa monetisasi dan hak perlindungan konten (copyright) dapat dipenuhi oleh YouTube setelah channel memiliki lebih dari 4.000 jam waktu tonton publik dalam 12 bulan terakhir dan memiliki lebih dari 1.000 subcriber.

Jika ketentuan tersebut belum terpenuhi semuanya, maka hak monetisasi dan perlindungan konten tidak akan dipenuhi. Seperti pada kasus channel milik Sam Pradana, seorang YouTuber Pemula yang belum mampu melakukan monetisasi dari konten miliknya karena belum memiliki batas minumum subcriber, meskipun jumlah penonton telah mencukupi. Hal ini menunjukan 
bahwa jika salah satu komponen persyaratan belum terpenuhi, maka monetisasi dan hak perlindungan konten tidak akan terpenuhi.

"untuk mendongkrak popularitas, biasanya YouTuber bikin konten collab dengan YouTuber yang sudah memiliki nama. Kalau udah gitu kesepakatan monetisasi tergantung keduanya kalau teman biasanya gratis kalau enggak ya penghasilan dibagi dua atau bayar".

Hasil wawancara menyebutkan bahwa banyak cara yang dilakukan oleh YouTuber untuk meraih popularitas atau untuk memenuhi standar syarat minimum YPP, salah satunya adalah dengan cara membuat video collaboration antar sesama YouTuber untuk menarik viewer dan subcriber. Sehingga kewajaran YouTuber atas konten yang tidak menghasilkan keuntungan secara materil dianggap sebagai bentuk kesalahan YouTuber yang tidak pandai dan kreatif dalam membuat konten, namun YouTube tetap mendapatkan keuntungan komersil berupa konten yang telah diakses oleh khalayak.

\section{KESIMPULAN}

Perkembangan teknologi khususnya media baru sering membuat banyak perubahan dilingkup masyarakat, seperti pergeseran pemikiran terhadap profesi pekerjaan yang dapat dilakukan sesuai dengan kebebasan diri sendiri. Youtuber, dikenal sebagai profesi yang santai dan menghasilkan profit, banyak diminati oleh generasi milenial sebagai pekerjaan kreatif yang menjanjikan. Sehingga banyak yang memandang bahwa YouTuber merupakan profesi bagi orang yang memiliki kreatifitas tinggi.

Penelitian ini menunjukkan kesimpulan sebagai berikut. Pertama, proses komodifikasi pekerja YouTuber tidak disadari oleh YouTuber itu sendiri dan masyarakat, proses tersebut berjalan sepanjang seseorang bekerja sebagai YouTuber. Komodifikasi tersebut berupa kepemilikan konten yang dimiliki sepenuhnya oleh YouTube, sehingga YouTube mampu mengendalikan upah atau monetisasi bagi YouTuber melalui standar yang ditetapkan oleh YouTube.

Kedua, YouTube melakukan eksploitasi mutlak kepada YouTuber baik yang telah meraih sertifikasi berupa button play, underrated dan pemula melalui bentuk digital labor, yaitu tidak adanya batas jam kerja dan self production atau memproduksi konten secara mandiri. Sedangkan eksploitasi relatif yang dialami oleh YouTuber dapat dilihat melalui self promotion atau promosi untuk akun channel miliknya yang menyasar audiens lokal maupun internasional untuk menunjang perolehan subcriber dan viewer agar mendapatkan profit yang lebih besar.

Ketiga, proses komodifikasi pekerja Youtuber pemula dan underrated terjadi karena adanya proses alienasi, mistifikasi, reifikasi dan naturalisasi. Alienasi yang terjadi kepada YouTuber berupa proses pembuatan konten yang dilakukan tanpa batas waktu yang tidak ditentukan, sehingga YouTuber tidak memiliki waktu untuk dirinya sendiri dan selalu berfokus pada konten yang akan disuguhkan kepada khalayak, terlebih bagi YouTuber pemula dan underrated yang tidak dapat menikmati sepenuhnya hasil kerja dan kreativitas yang telah dilakukan. Mistifikasi terjadi melalui pengembangan makna-makna YouTuber sebagai sosok yang memiliki pengaruh di dunia digital kreatif sebagai influencer digital. Reifikasi terjadi melalui pemaknaan YouTuber sebagai profesi yang berbeda dari profesi lainnya yang dipandang sebagai profesi yang menuntut seseorang memiliki tingkat kreatifitas yang tinggi. Naturalisasi yang dialami oleh YouTuber pemula dan underrated berupa adaptasi dari YouTube Partner Program (YPP) yang melihat bentuk kewajaran dengan menerima secara sadar dari tidak adanya proses monetisasi melalui konten yang diunggah di platform YouTube jika belum memenuhi standar kelayakan yang telah ditetapkan melalui YPP.

Melalui penelitian ini, peneliti banyak menemukan dimensi-dimensi lain yang tidak dapat dijelaskan karena adanya keterbatasan penelitian. Seperti pada kebijakan Revenue per-Mille Impression (RPM), yang ternyata membuat sekat pembatas penghasilan berdasarkan garis batas negara. Berdasarkan wawancara yang dilakukan, banyak YouTuber yang menyayangkan perbedaan pendapatan yang dilihat dari batas negara. 
Bahkan Indonesia menempati negara dengan monetisasi terendah dibandingkan dengan Youtuber asal negara maju seperti Amerika Serikat, Singapura dan Korea Selatan. Untuk itu, peneliti berharap agar penelitian dimasa depan mampu mengulas mengenai struktur monetisasi YouTube berdasarkan batas negara yang dapat dilihat menggunakan dimensi lain dari ekonomi politik komunikasi.

\section{DAFTAR PUSTAKA}

Andrejevic, M. (2009). Exploiting Youtube: Contradictions of User-Generated Labor. In P. \&. Snickar, Youtube Reader (pp. 406-423). Stockholm: National Library of Sweden.

Endah P, C. (2011). Memahami Studi Kasus sebagai Metode Penelitian. In A. \&. Ishak, Mix Methodology Dalam Penelitian Komunikasi ASPIKOM (pp. 199232). Yogyakarta: Mata Padi Pressindo.

Fuchs, C. \& Dyer-W, N. (2012). Karl Marx @Internet Studies. New Media \& Society Sage Publication, 1-16.

Fuchs, C. \&. Sevignani, S (2013). What is Digital Labour? What is Digital Work? What's their Difference? And Why do theese questions matter for understanding social media?, tricple $C$ : Communication, Capitalism \& Critique, 273-293.

Hecto, P. (2014). The socio-tehnical architecture of digital labor: Converting play into YouTube money . New Media \& Society Sage Publication, 1-17.

Herdiansyah, H. (2010). Metode Penelitian Kualitatif. Jakarta: Salemba Humanika.

Kriyantono, R. (2006). Teknik Praktis Riset Komunikasi. Jakarta: Kencana Prenada Media Group.

Labas, N. Y. \& Yasmine, I. (2017). Komodifikasi di Era Masyarakat Jejaring: Studi Kasus Youtube Indonesia. Jurnal Pemikiran Sosiologi Volume 4 No.2 UGM, 104-119.

Lessig, L. (2008). Remix Making Art and Commerce Thrive in the Hybrid Economy. London: Bloomsbury Publishing PLC.

Moeleong, L. J. (2013). Metodologi Penelitian Kuali- tatif. Bandung, Indonesia: PT. Remaja Rosda karya. Mosco, V. (2009). The Political Economy of Communication Second Edition. London: Sage Publication Ltd.

Muzairi. (2014). Fetisisme Komoditi dan Mistifikasi dalam Iklan. Refleksi UIN Sunan Kalijaga, 194-203.

Praditya, D. (2019, 5 20). TECHINASIA. Retrieved from TECHINASIA: https://id.techinasia.com/faktaperkembangan-youtube-di-indonesia

Pratopo M, W. (2017). Komodifikasi Wartawan di Era Konvergensi: Studi Kasus Tempo. Jurnal Komunikasi Indonesia, 129-138.

Rahmiaji, R. L. (2016). Komodifikasi Pekerja Anak Di Industri Sinetron Indonesia (Naturalisasi Eksploitasi Pekerja Anak Di sinetron Raden Kian Santang). Universitas Indonesia.

Subandi, E. Z. \& Sadono, P. T. (2018). Komodifikasi, Spasialisasi dan Strukturalisasi dalam Media Baru di Indonesia. National Conference of Creative Industry (pp. 822-842). Jakarta: Universitas Bunda Mulia.

Sunarto. (2011). Paradigma dan Metode Penelitian Komunikasi di Indonesia. In A. \&. Ishak, Mix Methodology Dalam Penelitian Komunikasi ASPIKOM (pp. 326). Yogyakarta: Mata Padi Pressindo.

Suseno-Magnis, F. (1999). Pemikiran Karl Marx. Jakarta: PT Gramedia Pustaka Utama.

Wasko, J. \&. Erickson, M. (2009). The Political Economy of Youtube, Youtube Reader. In P. \&. Snickars, Youtube Reader (pp. 282-283). Stockholm: National Library of Sweden.

YouTube. (2019, May 15). YouTube . Retrieved from YouTube: https://www.youtube.com/intl/id/creators/ partner-managers/ 